\title{
LUNG CYTOTOXICITY OF COMBINED EXPOSURE TO REFRACTORY CERAMIC FIBRES AND CIGARETTE SMOKE
}

\author{
Silvia Černá, Marta Hurbánková, Zuzana Kováčiková, Milan Beňo, Soňa Wimmerová
}

\author{
Slovak Medical University, Bratislava, Slovak Republic \\ e-mail:silvia.cerna@szu.sk
}

Received: June 10, 2005; Accepted: September 25, 2005

Key words: Lungs/Bronchoalveolar lavage/Refractory ceramic fibres/Smoking/Cytotoxicity/Lysosomal enzymes

Changes in some lung cytotoxic parameters after exposure to refractory ceramic fibres (RCF) or to cigarette smoke (S) and after combined exposure to $\mathrm{RCF}+\mathrm{S}$ were studied in male Wistar rats in order to evaluate their potential adverse health effects. Four groups of rats were treated as follows : 1) intratracheally instilled by saline solution $(0.4 \mathrm{ml}) ; 2)$ intratracheally instilled by $4 \mathrm{mg}$ of RCF; 3 ) exposed only to S ( $85 \mathrm{mg}$ of total particulate matter/ $\mathrm{m}^{3}$ air ) for two hours daily; 4) exposed to RCF+S. After 6 months the animals were exsanguinated and the bronchoalveolar lavage (BAL) was perfomed. Viability and phagocytic activity of alveolar macrophages (AM), activity of lactate dehydrogenase (LDH) in cell-free BAL fluid (cfBALF), acid phosphatase (ACP) and cathepsin D (CATD) in cfBALF, in BALF cells and in the lung tissue were estimated. Viability of AM was depressed by every type of exposure with $\mathrm{RCF}+\mathrm{S}$ effect being at least additive. Phagocytic activity of AM increased in the presence of RCF. No significant changes in LDH activity were found. Activities of lysosomal enzymes measured in the lung tissue homogenates were not significantly changed, but those in the cfBALF increased especially after exposure to $\mathrm{S}$ with most expressive increase in BALF cells after exposure to $\mathrm{S}$ and $\mathrm{RCF}+\mathrm{S}$. In the case of $\mathrm{CATD}$ the effect of $\mathrm{RCF}+\mathrm{S}$ was more than additive. The results point out to the persistence of the RCF exposure cytotoxic effects and their amplification by cigarette smoke.

\section{INTRODUCTION}

RCF - amorphous or partially crystalline materials made from kaolin clay or oxides of aluminium or other metal oxides ${ }^{1}$ have many properties (e.g. low heat storage, low thermal conductivity, resistance to thermal shock, chemical resistance) supporting their utility as an excellent isulating material ${ }^{2}$. Nowadays, after banning of asbestos use in most of the countries, RCF together with other man made vitreous fibres (MMVF) are getting into centre od interest. They are used as asbestos substitutes expecting their lower impact on the human and environmental health. Currently produced RCF contain fibres with the diameter distribution within the respirable range ${ }^{3}$. In vitro studies of RCF dissolution showed, that RCF are dissolved more rapidly than amosite fibres, but slower than other MMVF (ref. ${ }^{4}$ ). RCF belong to fibres with long biodurability $^{5-7}$ comparable with amosite and dependent on the lenght of fibres. It is supposed that the clearance of short fibres is accomplished primarily by macrophages and that of long fibres by dissolution and disintegration ${ }^{4}$. Regarding to the mentioned properties (respirability, biodurability) a negative influence of RCF exposure on the respiratory system can be expected. Studies on rodents including the inhalation studies ${ }^{8-11}$ showed that exposure to higher doses of RCF (ref. ${ }^{8,9}$ ) resulted in pulmonary fibrosis and increases of the number of lung tumours and mesotelioma. RCF are generally considered to be rodent carcinogens ${ }^{3}$. International Agency for Research on Cancer inserted RCF into Group 2B of carcinogenic risks to humans - possibly carcinogenic ${ }^{12}$. According to the results of epidemiolgical studies summarised in the work of Venturin et al. ${ }^{3}$ exposure to RCF caused elevated incidence of pleural plaques without evidence of fibrosis, mesothelioma or incremental lung tumours. Cowie at al. ${ }^{13}$ found some association between small opacities and cummulative exposure to RCF. Inverse relation between pulmonary function and exposure to fibres was found only in smokers. A negative synergism between RCF exposure and smoking might be expected ${ }^{3}$. The aim of our work was to follow the cytotoxic effect on lung tissue after experimental exposure of rats to combined RCF and cigarette smoke.

\section{MATERIAL AND METHODS}

The used RCF fibres (Carbolane fibres - Saint Gobain Ceramiques Industrielles, Nanterre, France ) including their characterisation were kindly supplied by Dr. E. Tatrai, Fodor Jozsef National Center for Public Health., Budapest, Hungary. The length and diameters of them are in Table 1.

Male Wistar rats (VELAZ, Prague, Czech Republic) weighing at the beginning of the experiment $152.9 \pm 6.6 \mathrm{~g}$ were divided into 4 groups and treated as follows: 1. group 
Table 1. Distribution of ceramic refractory fibres.

\begin{tabular}{|c|c|c|c|}
\hline $\begin{array}{c}\text { fibre diameter } \\
(\mu \mathrm{m})\end{array}$ & $\%$ & $\begin{array}{c}\text { fibre lenght } \\
(\mu \mathrm{m})\end{array}$ & $\%$ \\
\hline$<1$ & 6 & $20-40$ & 17 \\
\hline$=1$ & 12 & $41-60$ & 11 \\
\hline$<3$ & 35 & $61-80$ & 14 \\
\hline$=3$ & 8 & $81-100$ & 14 \\
\hline$>3$ & 39 & $>100$ & 44 \\
\hline
\end{tabular}

Composition of fibres: $\mathrm{SiO}_{2} 45-60 \% \mathrm{Al}_{2} \mathrm{O}_{3} 40-55 \%$

(control) - intratraechally instilled by $0.4 \mathrm{ml}$ of saline solution administered in two $0.2 \mathrm{ml}$ doses; 2 . group - intratracheally instilled by $4 \mathrm{mg}$ of refractory ceramic fibres (RCF) administered in two $2 \mathrm{mg}$ doses in the form of suspension in saline solution ( $1 \mathrm{mg}$ RCF $/ 0.1 \mathrm{ml}$ saline solution); 3. group- exposed to diluted mainstream cigarette smoke (S) at the concentration of $85 \mathrm{mg}$ of total particulate matter (TPM) $/ \mathrm{m}^{3}$ air for two hours daily (except Saturdays and Sundays) in a whole-body exposure chamber (THRI, Lexington, USA) reaching this concentrattion by burning 8 standard research cigarettes 1R1 type (THRI, Lexington, USA); 4. group - intratracheally instilled by $4 \mathrm{mg}$ RCF (as group 2) and exposed to $\mathrm{S}$ (as group 3). Six months after beginning of the exposure the animals were anaesthesized by thiopental $(150 \mathrm{mg} /$ $\mathrm{kg}$ ) and exsanguinated by cutting the vena cava caudalis. Bronchoalveolar lavage (BAL) was performed by modi- fied method of Myrvik ${ }^{13}$. After estimation of the viability ${ }^{14}$ of AM the bronchoalveolar lavage fluid (BALF) was centrifuged at $400 \mathrm{~g}$ for 10 minutes at $4{ }^{\circ} \mathrm{C}$, the cell-free BALF (cfBALF) was transfered into clean cooled glass tubes and the cell sediment adjusted by strerile saline solution to $1 \times 10^{6}$ cells $/ \mathrm{ml}$. The lungs were perfused and $10 \%$ stock homogenate in phosphate buffered saline (PBS) was prepared. Lactate dehydrogenase (LDH) was measured immediately (LD 105 UV Lachema Brno, Czech Republic). Acid phosphatase (ACP) in cfBALF (Acid phosphatase AC 565, Randox Laboratories, Antrim, UK) was measured during the day of BAL performance. The rest of cfBALF, the cell sediments and the lung tissue homogenates were stored at $-70{ }^{\circ} \mathrm{C}$ until they were analysed. The cell sediments were resuspended in TRITON X100 dissolved in PBS and the tissue homogenates were rehomogenized in Triton X100 (final concentration of TRITON in a sample was $0.1 \%)^{15}$. After 3 times repeated freezing and thawing the treated cell sediments and tissue homogenates were centrifuged at $15000 \mathrm{~g}$ for 20 minutes at $4{ }^{\circ} \mathrm{C}$. Activities of the lysosomal enzymes were measured in the supernatants ${ }^{16,17}$.

Mann-Whitney test was used for the comparison of values from chosen groups.

\section{RESULTS AND DISCUSSION}

Viability of AM significantly decreased after all types of exposure (Fig. 1). This indicated the duration of cytotoxic effect of RCF and confirmed the expected cytotoxicity of cigarette smoke. Exposure to cigarette smoke amplified the negative effect of RCF more than additively. Exposure to $\mathrm{S}$ alone, similarly as in our previous work ${ }^{18}$,

Table 2. Activity of lactate dehydrogenase, acid phosphatase and cathepsin D in cell-free bronchoalveolar lavage fluid and lung tissue homogenates

\begin{tabular}{|c|c|c|c|c|}
\hline enzyme & $\mathrm{C}$ & $\mathrm{RCF}$ & $\mathrm{S}$ & $\mathrm{RCF}+\mathrm{S}$ \\
\hline \multicolumn{5}{|c|}{ cell-free-bronchoalveolar lavage fluid } \\
\hline $\begin{array}{l}\text { LDH } \\
\mu \text { kat.g protein }{ }^{-1}\end{array}$ & $\begin{array}{c}6.47 \\
(4.22 ; 7.82) \\
\end{array}$ & $\begin{array}{c}5.31 \\
(3.96 ; 6.99) \\
\end{array}$ & $\begin{array}{c}7.56 \\
(7.12 ; 8.45) \\
\end{array}$ & $\begin{array}{c}6.01 \\
(5.86 ; 6.48) \\
\end{array}$ \\
\hline $\begin{array}{l}\text { ACP } \\
\text { nkat.g protein }{ }^{-1}\end{array}$ & $\begin{array}{c}59.97 \\
(54.29 ; 69.07)\end{array}$ & $\begin{array}{c}61.13 \\
(49.27 ; 83.64)\end{array}$ & $\begin{array}{c}90.65 * \uparrow \\
(83.40 ; 96.37)\end{array}$ & $\begin{array}{c}67.39 \\
(58.63 ; 78.82)\end{array}$ \\
\hline $\begin{array}{l}\text { CATD } \\
\mathrm{U}_{\mathrm{tyr}} \cdot \mathrm{mg} \text { protein }^{-1}\end{array}$ & $\begin{array}{c}63.39 \\
(57.54 ; 67.66) \\
\end{array}$ & $\begin{array}{c}67.95 \\
62.12 ; 77.29) \\
\end{array}$ & $\begin{array}{c}95.69 * \uparrow \\
(83.95 ; 124.09) \\
\end{array}$ & $\begin{array}{c}94.06 * \uparrow \\
(91.71 ; 105.15) \\
\end{array}$ \\
\hline \multicolumn{5}{|c|}{ lung tissue homogenates } \\
\hline $\begin{array}{l}\text { ACP } \\
\text { nkat.mg protein }^{-1}\end{array}$ & $\begin{array}{c}0.49 \\
(0.41 ; 0.55) \\
\end{array}$ & $\begin{array}{c}0.53 \\
(0.48 ; 0.63) \\
\end{array}$ & $\begin{array}{c}0.50 \\
(0.31 ; 0.62) \\
\end{array}$ & $\begin{array}{c}0.46 \\
(0.27 ; 0.53) \\
\end{array}$ \\
\hline $\begin{array}{l}\text { CATD } \\
\mathrm{U}_{\mathrm{tyr}} \cdot \mu \mathrm{g} \text { protein }^{-1}\end{array}$ & $\begin{array}{c}0.29 \\
(0.18 ; 0.35) \\
\end{array}$ & $\begin{array}{c}0.35 \\
(0.28 ; 0.41) \\
\end{array}$ & $\begin{array}{c}0.38 \\
(0.33 ; 0.41) \\
\end{array}$ & $\begin{array}{c}0.36 \\
(0.21 ; 0.43) \\
\end{array}$ \\
\hline
\end{tabular}

Values represent medians and $25^{\text {th }}$ and $75^{\text {th }}$ percentiles.

$\mathrm{C}$ - control group., RCF - group exposed to refractory ceramic fibres, $\mathrm{S}$ - group exposed to cigarette smoke, $\mathrm{RCF}+\mathrm{S}-\mathrm{group}$ exposed to refractory ceramic fibres and cigarette smoke, LDH - lactate dehydrogenase, ACP - acid phosphatase, CATD - cathepsin D, $\mathrm{U}_{\mathrm{tyr}-} \mu \mathrm{g}$ of tyrosine released in an hour time. Comparison with control group: * $\mathrm{P}<0.05, \uparrow-$ increase . 


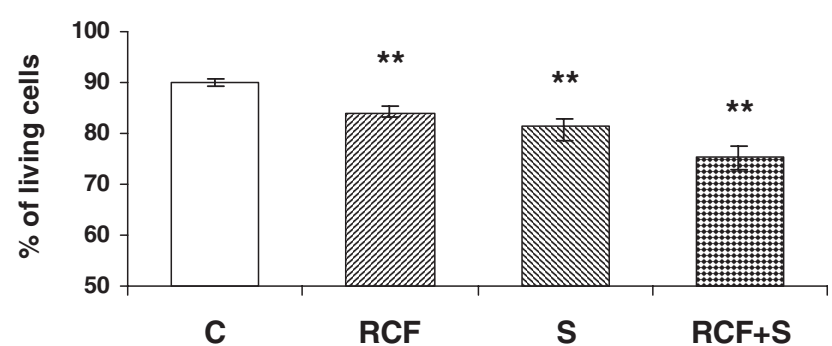

Fig. 1. Viability of alveolar macrophages after exposure to ceramic refractory fibres and cigarette smoke. C - control group, RCF - group exposed to ceramic refractory fibres, $\mathrm{S}$ - group exposed to cigarette smoke, $\mathrm{RCF}+\mathrm{S}$ - group exposed to ceramic refractory fibres and cigarette smoke. Comparison with the control group: ${ }^{* *} \mathrm{p}<0.01$.

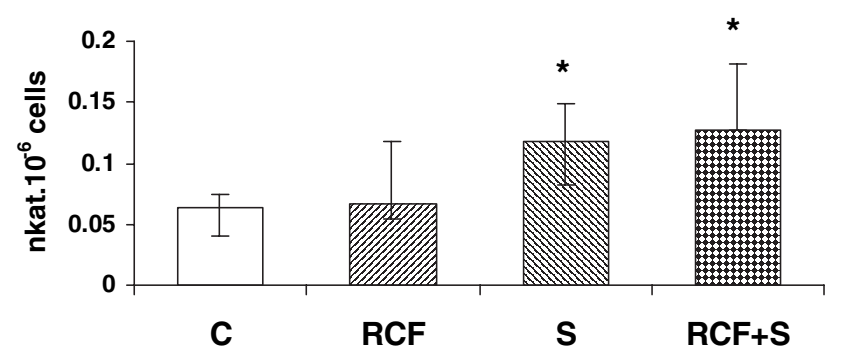

Fig. 3. Acid phosphatase activity in bronchoalveolar lavage cells after exposure to ceramic refractory fibres and cigarette smoke. C - control group, RCF - group exposed to refractory ceramic fibres, $\mathrm{S}$ - group exposed to cigarette smoke, $\mathrm{RCF}+\mathrm{S}$ - group exposed to ceramic refractory fibres and cigarette smoke. Comparison with the control group: * $\mathrm{p}<0.05$

significantly depressed the phagocytic activity of AM (Fig. 2). Contratry to amosite, the tested RCF stimulated the phagocytic activity.

Enzyme activities in cfBALF and in lung tissue homogenates are shown in Table 2. Increase in the activity of LDH - a cytosolic enzyme - and in the activity of lysosomal enzymes in extracellular fluids are considered to be the consequence of the leakage of these enzymes from the damaged tissue ${ }^{19-21}$ and in the case of cfBALF also of the leakage from $\mathrm{AM}^{22-24}$. Activity of $\mathrm{LDH}$ in this experiment was not significantly influenced by any of tested exposures (Table 2). We measured the LDH activity six months after instillation. Results of the report of inhalation study with $\mathrm{RCF}$ in rats $^{25}$ showed, that the differences in LDH activities between control and exposed groups disappeared between the $31^{\text {th }}$ and $93^{\text {th }}$ day after end of RCF inhalation. Significantly higher activities of lysosomal enzymes in cfBALF were found only after exposure to $\mathrm{S}$ alone or in the case of CATD also after combined exposure (Table 2).

Exposure to RCF alone did not change the ACP activity in BALF cells (Fig. 3). This fact together with the similarity of significant increase in ACP activity after ex-

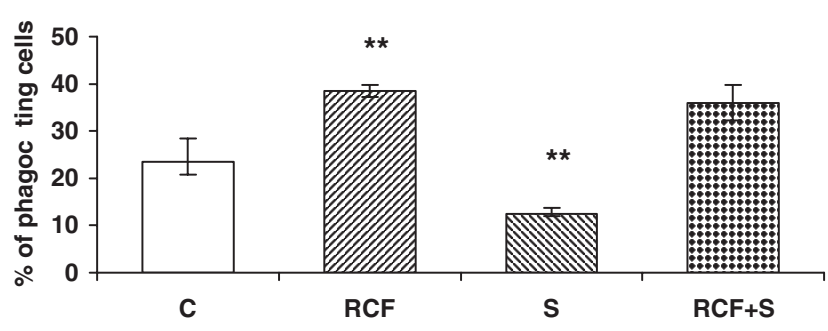

Fig. 2. Phagocytic activity of alveolar macrophages after exposure to ceramic refractory fibres and cigarette smoke. C - control group, RCF - group exposed to ceramic refractory fibres, $\mathrm{S}$ - group exposed to cigarette smoke, $\mathrm{RCF}+\mathrm{S}$ - group exposed to ceramic refractory fibres and cigarette smoke. Comparison with the control group: ** $\mathrm{p}<0.01$.

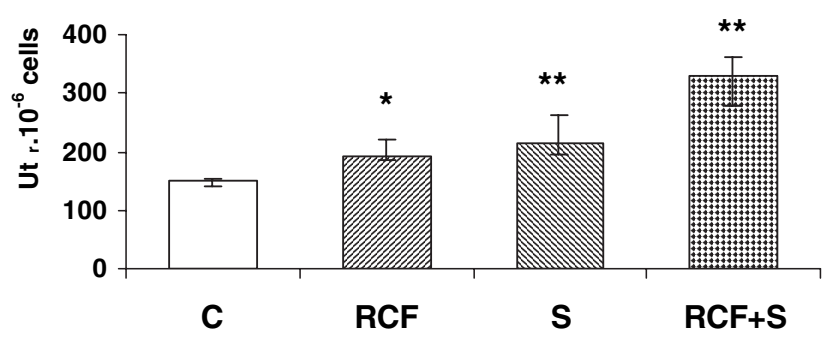

Fig. 4. Cathepsin D activity in bronchoalveolar lavage cells after exposure to ceramic refractory fibres and cigarette smoke. C - control group, RCF - group exposed to ceramic refractory fibres, $\mathrm{S}$ - group exposed to cigarette smoke, $\mathrm{RCF}+\mathrm{S}$ - group exposed to ceramic refractory fibres and cigarette smoke, $\mathrm{U}_{\mathrm{tyr}}-\mu \mathrm{g}$ of tyrosine released in an hour time Comparison with the control group: * $\mathrm{p}<0.05$; ** $\mathrm{p}<0.01$.

posure to $\mathrm{S}$ and to $\mathrm{RCF}+\mathrm{S}$ indicates that the influence of smoke on the ACP activity was much more expressive than the influence of RCF. Significant increase of cathepsin $\mathrm{D}$ activity after all types of exposure confirmed the sensitivity of this parameter at the evaluation of lung cytotoxicity of examined respirable substances ${ }^{18}$. In combined exposure the effect of examined substances was more than additive. Most of the articles dealing with the activities of lysosomal enzymes in AM after in vivo or in vitro exposure to respirable substances describe the intra - and extracellular concentration or activity of these enzymes after incubation of the isolated AM in the medium. Increased (often dose dependent) leakage into the medium (and consequently decreased activities in the intracellular space) are mentioned ${ }^{20,26-28}$. We did not incubate the isolated BAL cells because we did not want to monitor the leakage of lysosomal enzymes. The activities of lysosomal enzymes we measured were the activities at the time of BAL performance. The most expressive changes were found in the cathepsin D activity (Fig. 4). This aspartyl endoprotease is closely associated with tumour progression in some human malignancies including 
lung adenocarcinoma ${ }^{29}$, it is overexpressed in inflammatory status ${ }^{30}$ and modulated by inflammatory mediators. Cigarette smoke was described as a potent inducer of this enzyme activity in $\mathrm{AM}^{31}$.

Examination of the effect of RCF cigarette smoke on cells in lung tissue results into the following conclusions: (i) The expected cytotoxicity of RCF was confirmed by the significant decrease in viability of AM, significant increase in CATD activity in cfBALF, and significant increase in ACP and CATD activity in BALF cells; (ii) Cytotoxic activity of cigarette smoke was demonstrated by the significant decrease in viability of AM, significant decrease in phagocytic activity of AM, significant increase of ACP and CATD activity in cfBALF, and significant increase of ACP and CATD activity in BALF cells. (iii) Exposure to cigarette smoke amplified the negative effect of RCF. (iv) Cathepsin D activity was the most sensitive indicator of cytotoxic effects of tested substances.

\section{ACKNOWLEDGEMENT}

The autors wish to express their thanks to Mrs Helena Bobeková, Mrs Mária Valentová, Ing. Marta Staruchová, RNDr. Katarína Volkovová PhD, Mrs. Darina Čepcová, Mrs. Jarmila Jantošková and Miss Lubica Miklošková for their excellent assistance.

\section{REFERENCES}

1. Foa V, Basilico S. (1999) Chemical and physical characteristics and toxicology of man made mineral fibres. Med Lav 90, 10-52.

2. Maxim LD, Allshouse JN, Chen SH, Treadway JC, Venturin DE. (2000) Workplace Monitoring of Refractory Ceramic Fiber in the United States. Regul Toxicol Pharmacol 32, 293-309.

3. Venturin D, Deren G, Corn M. ( 1997) Qualitative Industrial Hygiene Product Life Cycle Analysis Apllied to Refractory Ceramic Fiber (RCF) Consumer Product Applications. Regul Toxicol Pharmacol 25, 232-9.

4. Searl A, Buchanan D, Cullen RT, Jones AD, Miller BG, Soutar CA. (1999) Biopersistence and durability of nine mineral fiber types in rat lungs over 12 months. Ann Occup Hyg 43, 143-53.

5. Mühle H, Bellman B. (1995) Biopersistence of man-made vitreous fibres. Ann Occup Hyg 39, 655-60.

6. Yamato H, Hori H, Tanaka I, Higashi T, Morimoto Y, Kido M. (1994) Retention and clearance of inhaled ceramic fibres in rat lungs and development of dissolution model. Occup Environ Med 51, 275-80.

7. Dufrense A, Perrault G, Yamato H, Masse S, Begin R. (1999) Clearance of man made mineral fibres from the lungs of sheep. Occup Environ Med 56, 684-90.

8. Mast RW, Hesterberg TW, Glass LR, McConnel EE, Anderson R, Bernstein DM. (1994) Chronic inhalation and biopersistence of refractory ceramic fibres in rats and hamsters. Environ Health Perspect 102, suppl. 5, 207-9.

9. Hesterberg TW, Müller WC, Thevenaz P, Anderson R. ( 995) Chronic inhalation studies of man-made vitreous fibres: chtracterization of fibres in the exposure aerosol and lungs. Ann Occup Hyg 39, 661-72.

10. Bernstein DM, Thevenaz P, Fleissner H, Anderson R, Hesterberg TW, Mast R. (1995) Evaluation of oncogenic potential of manmade vitreous fibres: the inhalation model. Ann Occup Hyg 39, $661-72$.

11. Rossiter CE, Chase JR. (1995) Statistical analysis of results of carcinogenity studies of synthetic vitreous fibres at Research and Consulting Company, Geneva. Ann Occup Hyg 39, 759-69.
12. International Agency for Research on Cancer (IARC). Man- Made Mineral Fibres. In: Man-Made Mineral Fibres and Radon. Lyon: IARC, 1988. p. 39-71.

13. Cowie HA, Wild P, Beck J, Auburtin G, Piekarsky C, Massin N, Cherrie JW, Hurley JF, Miller BG, Groat CA. ( 2001) An epidemiological study of workers in European refractory ceramic fiber industry. Occup Environ Med 58, 800-10.

14. Hurbánková M, Keiglová A. (1999) Compared effects of asbestos and wollastonite fibrous dusts on various biological parameters measured in bronchoalveolar lavage fluid. J Trace Microprobe Tech 17, 233-43.

15. Navarová J, Nosál'ová V. (1994) Effects of H2 receptor antagonists on indometacin induced lysosomal enzyme release from gastric mucosa. Meth Fin Exp Clin Pharmacol 16,119-24,

16. Barrett AJ, Heath MF. Lysosomal enzymes. In: Dingle JT.editor. Lysosomes: Laboratory Handbook, $2^{\text {th }}$ ed. Amsterdam: Elsevier, 1977. p. 19-147.

17. Navarová J, Seemanová Z, Ulházy E, Šotníková R, Dubovický M, Muchová S, Horáková K. (2000) Biochemical variables of oxidative cell and tissue damage induced by phenytoin. Biologia 55, Suppl 8 , S20-23.

18. Černá S, Beňo M, Hurbánková M, Kováčiková Z, Bobek P, Kyrtopoulos SA. (2004) Evaluation of bronchoalveolar lavage fluid cytotoxic parameters after inhalation exposure to amosite and wollastonite fibrous dusts combined with cigarette smoke. Centr Eur J Publ Health 12, Suppl 2, S20-3.

19. Drent M, Cobben NAM, Henderson RF, Wounters EFM, DieijenVisser van MP. (1996) Usefulness of lactate dehydrogenase and its isoenzymes as indicators of lung damage or inflammation. Eur Respir J 9, 2416-8.

20. Sjörstrand M, Rylander R. (1987) Lysosomal enzyme activity and fibroblast stimulation of lavage from guinea pigs exposed to silica dust. Br J Exp Path 68, 309-18.

21. Sjörstrand M, Rylander R. (1984) Lung cell reaction in guinea pigs exposed to tobacco smoke and silica dust or bacterial lipopolysaccharides. Toxicology 29, 271-80.

22. Kim KA, Lee WK, Kim JK, Seo MS, Lim Y, Lee KH, Chae G, Lee SH, Chung Y.( 2001) Mechanism of refractory ceramic fiber- and rockwool-induced cytotoxicity in alveolar macrophages. Int Arch Occup Environ Health 74, 9-15.

23. Jaurand MC, Magne L, Bignon J, Goni J. (1980) Effects of welldefined fibres on red blood cells and alveolar macrophages. IARC Sci Publ 30, 441-50.

24. Schimmelpfeng J, Seidel A. (1991) Cytotoxic effects of quartz and chrysotile asbestos: in vitro interspecies comparison with alveolar macrophages. J Toxicol Environ Helath 33, 131-40.

25. Fraunhofer Institute of Toxicology and Aerosol Research. Final Report on a Short-Term Inhalation Study with RCF1 in Rats. Study 02G97012. Hannover, 2001.

26. Rylander R, Fogelmark B, Sjörstrand M. (1985) Free lung cell phagocytosis and lysosomal enzyme activity after inhalation of lipopolysaccharide in guinea pigs. Agents Action 16, 353-8.

27. Atwood EM, Weich DJ, Oosthuizen JM. (1996) The influence of carbon particles on the concentration of acid phosphatase and lysosomal enzyme within alveolar macrophages during killing and degradation of Mycobacterium bovis. Tuber Lung Dis 77, 341-7.

28. Sulciman SA. (1987) Petroleum hydocarbon toxicity in vitro: effects of n-alkanes, benzene and toluene on pulmonary alveolar macrophages and lysosomal enzymes of lungs. Arch Toxicol 59, 402-7,

29. Higashiyama M, Doi O, Kodama K, Yokouchi H, Kasugai T, Ishiguro S. (1997) Influence of cathepsin D expression in lung adenocarcinoma on prognosis: possible importance of its expression in tumor cells and stromal cells, and its intracellular polarization in tumor cells. J Surg Oncol 65, 10-9.

30. Hausmann M, Obermeier F, Schreiter K, Spott T, Falk W, Scholmerich J, Herfarth H, Saftig P, Rogler G. (2004) Cathepsin is up-regulated in inflammatory bowel disease macrophages. Clin Exp Immunol 135, 157-67.

31. Chang JC, Yoo OH, Lesser M. (1989) Cathepsin D activity is increased in alveolar macrophages and bronchoalveolar lavage fluid of smokers. Am Rew Resp Dis 140, 958-60. 